\title{
KEBEBASAN BERAGAMA DALAM ISLAM
}

\author{
Oleh: \\ Tri Yuliana Wijayanti \\ Institut Agama Islam Negeri Batusangkar, Indonesia \\ Email: tri.yw@iainbatusangkar.ac.id
}

\begin{abstract}
Every human being is free to choose a religion according to his religious experience and in accordance with his personal beliefs. Freedom of religion also includes the situation conducive for people to choose religion (according to his) and to his religion without restriction and coercion from any party. The challenges of today's religious life in contrast to the issue of religious freedom and the fact of religious plurality. Religious pluralism urged all religions to think practically how to get along with other religious and theological interpret the meaning of the presence of religion and belief.
\end{abstract}

Kata kunci: Kebebasan beragama dan Islam.

\section{A. PENDAHULUAN}

Agama merupakan aturan atau tatacara hidup manusia dalam hubungannya dengan Tuhan dan sesamanya. Agama berfungsi sebagai pedoman hidup manusia, sehingga tercipta suatu hubungan serasi antara manusia dengan Yang Maha Pencipta (Team, 1990:125). Bagi pemeluknya, agama diyakini sebagai sesuatu yang luhur, yang menuntun ke jalan Tuhan sehingga terwujud keselamatan duniaakhirat. Agama dalam relasi antara manusia dengan Sang Pencipta, dinyatakan dalam bentuk yang kultus berdasarkan doktrin-doktrin tertentu. Singkatnya, agama sebagai kebutuhan yang paling mendasar dan sebagai sumber pedoman kehidupan manusia.
Dewasa ini, iklim kehidupan beragama semakin memprihatinkan dalam kewilayahan manapun. Kebebasan dalam memilih dan meyakini suatu agama telah terminimalisasi yang pada puncaknya meletup dalam tindak kekerasan terhadap manusia. Konflik tidak lain adalah efek langsung dari salah satu bentuk dinamika realita pluralitas. Ketika masyarakat yang berbeda agama atau suku saling berinteraksi, pada saat itu pula kemungkinan terjadinya konflik menjadi sangat terbuka (Th Sumartana; Noegroho Agoeng; dan Zuly Qodir, 2002: 9). Dengan kata lain, konflik dapat terjadi secara alamiah sebagai konsekuensi logis dari perbedaan teologi.

Secara hakiki, setiap manusia memiliki hak yang melekat pada 
dirinya sejak ia lahir. Salah satunya ialah hak atas kebebasan beragama. Setiap manusia bebas memilih agama sesuai dengan pengalaman religiusnya dan sesuai dengan keyakinan pribadinya. Tentu kebebasan beragama ini bukan hanya sebagai suatu kemampuan, melainkan juga sebagai suatu kondisi real yang dialami oleh manusia. Artinya, kebebasan beragama juga memuat adanya situasi kondusif bagi seseorang untuk memilih agama (sesuai dengan keyakinannya) dan untuk menghayati agamanya tanpa adanya hambatan dan paksaan dari pihak manapun.

Tantangan hidup beragama pada dewasa ini bertolak pada persoalan kebebasan beragama dan fakta adanya pluralitas agama. Kemajemukan agama mendesak setiap agama untuk berpikir praktis bagaimana bergaul dengan agama lain serta memaknai secara teologis makna kehadiran agama-agama dan kepercayaan itu.

Islam sebagai agama mayoritas, dituntut untuk mengupayakan terwujudnya landasan interaksi sosial yang mengutamakan sikap menghargai dan menghormati kebebasan beragama, sehingga klaim-klaim keselamatan dan kebenaran antaragama tidak terletupkan secara frontal melalui konflik.

Posisi kebebasan beragama dalam lingkup hak asasi manusia sangatlah penting. Sebagian besar kegiatan manusia dilindungi oleh pasal yang terkait dengan kebebasan beragama, berekspresi, dan berpolitik (Frans Sayogje, 2013:42). Oleh sebab itu, sangatlah tidak manusiawi jika segala macam bentuk kekerasan dan paksaan yang datang dari manapun juga bertujuan untuk memaksakan suatu agama kepada orang lain. Sikap saling pengertian itu hanya dapat terwujud dengan pembumian pemaknaan kebebasan beragama yang bernuansa toleransi.

Memperhatikan latar belakang tersebut, maka yang menjadi permasalahan dalam penelitian ini adalah bagaimana kebebasan beragama dalam Islam?. Memperhatikan permasalahan dalam penelitian ini, maka tujuan yang hendak dicapai adalah untuk mendeskripsikan kebebasan beragama dalam pandangan agama Islam.

Secara akademik, studi penelitian yang mengupas kebebasan beragama telah beberapa kali dilakukan. Penelitian-penelitian tersebut, antara lain: Pertama, penelitian Abdillah Halim pada tahun 2010 yang mengambil judul "Telaah Politik Hukum dan Kebebasan Beragama terhadap UU No. 1/PNPS/1965 tentang Pencegahan Penyalahgunaan dan/atau Penodaan Agama". Penelitian ini menerangkan bahwa kebebasan beragama merupakan anugerah dari Tuhan yang diberikan kepada setiap manusia dan tidak boleh dihapus dalam situasi dan dengan alasan apapun. Negara mempunyai peranan penting untuk mewujudkan dan menjamin keberlangsungannya. Dalam konteks negara Indonesia, keharusan negara untuk melindungi kebebasan beragama telah diatur dalam beberapa pasal, namun kewajiban tersebut justru dilanggar oleh pemerintah-era demokrasi terpimpin-dengan terbitnya Perpres No. 1/PNPS/1965 tentang pencegahan, penyalahgunaan, dan/atau penodaan agama. Perpres No. 1/PNPS/1965 
kemudian dikukuhkan menjadi UU No. 1/PNPS/1965 dan digunakan oleh pemerintahan-pemerintahan

selanjutnya sebagai payung hukum dan pembenar bagi pengawasan negara terhadap agama maupun kepercayaan masyarakat. UU No. 1/PNPS/1965 ini oleh sebagian kalangan dianggap bukan sebagai pengaturan, namun sebagai kontrol negara yang kontraproduktif kebebasan beragama.

Kedua, penelitian Hasyim Asy'ari pada tahun 2011 tentang "Politik Hukum Kebebasan Beragama di Indonesia." Penelitian yang diterbitkan dalam jurnal hukum Pandecta ini menyebutkan bahwa perkembangan politik hukum kebebasan beragama di Indonesia berjalan tidak linear, namun penuh dinamika sebagaimana pengalaman historis relasi antara negara dan agama yang terjadi selama ini. Relasi antara negara dengan Nahdlatul Ulama (NU) dijadikan model penelitian bagaimana dinamika relasi antara negara dan agama terjadi di Indonesia. Berdasarkan penelitian ini, perkembangan politik hukum kebebasan beragama di Indonesia tidak terlepas dari pandangan (persepsi/pemahaman) negara dan masyarakat, dan antar warga masyarakat. Oleh karena itu, Hasyim Asy'ari merekomendasikan perlunya membangun kesepahaman antara negara dengan masyarakat guna meredam konflik yang potensial melang-gar kebebasan beragama di Indonesia.

Ketiga, tesis dengan judul Hak Kebebasan Beragama Dalam Islam Ditinjau Dari Perspektif Perlindungan Negara Dan Hak Asasi Manusia Universal yang ditulis oleh Frans
Sayogie. Tesis ini mengupas konsep hak kebebasan beragama dalam Islam ditinjau dari perspektif perlindungan negara dan hak asasi manusia universal. Menurut Frans, implementasi kebebasan beragama dalam Islam masih berada pada tataran retorika. Piagam Madinah dengan tegas memberikan perlindungan kebebasan beragama dan memberikan hak-hak non muslim, namun dalam praktiknya justru dilanggar oleh negara Islam sendiri. Negara tidak bersikap netral terhadap semua doktrin keagamaan dan selalu berusaha menerapkan prinsip-prinsip syariah sebagai kebijakan-menformalisasi dan menerapkan rumusan syariah dalam ruang publik - atau perundangundangan negara. Deklarasi Kairo juga memberikan legitimasi kepada negaranegara Islam untuk tetap mempertahankan dan menjalankan doktrin berbasis syariah yang lebih menekankan terhadap perlindungan negara daripada memberikan perlindungan hak fundamental dalam kebebasan agama.

Oleh karena itu, Frans Sayogie mengusulkan negara Islam perlu menerapkan sekulerisasi yang bertujuan agar negara lebih independen dan diharapkan dapat memberikan perlindungan kepada organisasiorganisasi maupun institusi-institusi terhadap penyalahgunaan kekuasaan atas nama agama. Ia menegaskan bahwa kebebasan beragama hanya bisa dilaksanakan dalam kerangka kerja negara yang konstitusional dan demokratis didasarkan oleh semangat yang dianut hak asasi manusia universal. 


\section{B. METODOLOGI}

Berdasarkan

tempat penelitiannya, termasuk penelitian kepustakaan (library research), yang menfokuskan pada kajian kebebasan beragama dalam pandangan agama Islam. Untuk tipe penelitiannya, tergolong dalam lingkup penelitian diskriptif, yakni metode yang digunakan untuk mencari fakta dengan intepretasi yang tepat (Moh. Nazir, 1988:63). Penelitian ini mendiskripsikan sebagaimana adanya fenomena tersebut sesuai dengan sudut pandang atau pendekatan yang digunakan.

\section{Teknik}

dokumentasi dipergunakan dalam menghimpun datadata yang berupa buku-buku maupun artikel-artikel yang dirujuk dari jurnal online, cetak, maupun internet. Pengumpulan data dilakukan untuk memperoleh bahan-bahan yang relevan, akurat, dan reliabel (Kusdiyanto, 1997: 89).

Adapun penelitian ini merupakan penelitian kualitatif yang mana prosedur dalam penelitian menghasilkan data deskriptif baik berupa tulisan maupun lisan dari obyek yang diteliti (Lexy J. Moleong, 1994: 3). Data yang telah terkumpul kemudia dianalisa dan disimpulkan secara deduktif, yaitu menarik kesimpulan dari pernyataan umum menuju pernyataan khusus (Nana Sudjana, 1988: 5-6)

\section{HASIL DAN PEMBAHASAN}

\section{Pengertian Kebebasan Beragama}

Setiap manusia dilahirkan dalam keadaan bebas. Kebebasan mereka dalam kehidupan benar-benar mutlak dalam segala hal, hingga bertemu dengan kebenaran atau kebaikan. Hak kebebasan beragama merupakan hak yang esensi bagi manusia yang memungkinkan ia sanggup untuk menjawab dengan bebas panggilan kecintaan dari Tuhan dan untuk menjawab penciptanya. Hak untuk beriman secara bebas termasuk dalam kerangka kebebasan hati nurani perorangan. Kebutuhan untuk menjamin kebebasan beragama harus diikuti dengan perlindungan hak-hak asasi manusia yang lain, yakni hak berkumpul; mencari, menerima, dan memberikan penerangan, dan mengajarkan agama atau kepercayaan. Kebebasan beragama juga mendorong penerapan kebebasan agama atau kepercayaan dalam ranah sosial, ekonomi, dan politik dalam lingkup nasional maupun internasional (Mukti Ali, 1970 :33-34).

Kebebasan beragama difahami sebagai prinsip bahwa setiap individu bebas memilih dan mengimani agamanya serta mengamalkan sepenuhnya ajaran-ajaran agama yang diyakininya. Islam memberi kebebasan kepada warganya untuk memeluk agama masing-masing dan tidak diperbolehkan memaksakan keyakinannya kepada orang lain (Muhammad Alim, 2001: 95-96). Dengan demikian, maka tidak dibenarkan ada pihak-pihak lain untuk mengganggu-gugat hak yang paling dasar ini, baik berupa pengingkaran sepenuhnya atau hanya sekadar pereduksian.

Meskipun tidak ada kebenaran sekaligus kebaikan yang lebih baik daripada Islam dan meskipun setiap Muslim ditugaskan untuk mengajak manusia memeluk Islam dan 
mengemukakan argumen-argumen yang memperkokoh Islam, namun mereka tidak diminta menyebarkan iman dengan kekerasan. Siapa pun yang menerima Islam adalah melakukannya atas pilihannya sendiri. Muslim dituntut mengakui dan menghormati keputusan orang lain yang tidak menerima Islam dan dilarang menggunakan tekanan moral, sosial, ataupun politik yang dikenakan terhadap mereka untuk mengubah keyakinannya.

Setiap Muslim wajib menghormati dan menghargai hak asasi sesamanya, yang berupa jaminan atas hidup dan harta kekayaan, perlindungan kehormatan, kepribadian dan jaminan kehidupan pribadi, jaminan kebebasan pribadi, hak untuk menentang tirani, kebebasan mengeluarkan pendapat, kebebasan berserikat, kebebasan mengeluarkan ucapan hati nurani dan keyakinan, perlindungan terhadap sentimensentimen keagamaan, perlindungan dari penghukuman yang sewenangwenang, hak atas kebutuhan-kebutuhan hidup pokok, persamaan kedudukan di hadapan hukum, hak untuk menjauhi perbuatan dosa, dan hak ikut serta dalam urusan negara (Maulana Abul A'la Maududi, 2000: 22-40).

Praktek kebebasan memeluk dan menjalankan suatu agama dalam sejarah Islam sudah terjadi seperti diatur dalam Piagam Madinah dan Piagam Aelia di Jerusalem. Kaum nonmuslim diberi kebebasan menjalankan agama mereka dengan batasan-batasan tertentu. Kebebasan beragama bukan kebebasan untuk merusak agama atau menodai agama, karena pengrusakan atau penyelewengan ajaran Islam merupakan tindak krimina (Sarah Larasati Mantovani, 2011: 13).

\section{Dasar Kebebasan Beragama}

a. Al-Qur'an

1) Surat al-Baqarah

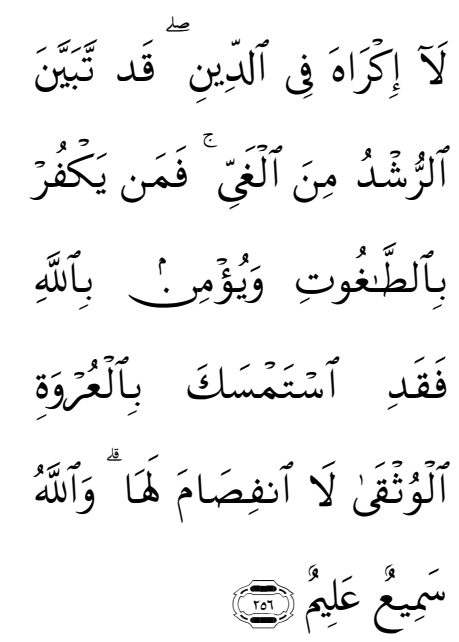

"Tidak ada paksaan dalam (menganut) agama (Islam), sesungguhnya telah jelas (perbedaan) antara jalan yang benar dengan jalan yang sesat. Barang siapa yang ingkar kepada Taghut dan beriman kepada Allah, maka sesungguhnya, dia telah berpegang (teguh) pada tali yang sangat kuat yang tidak akan putus. Allah Maha Mendengar Maha Mengetahui”" (Q.S. Al Baqarah, 2: 256).

2) Surat al-Kafirun

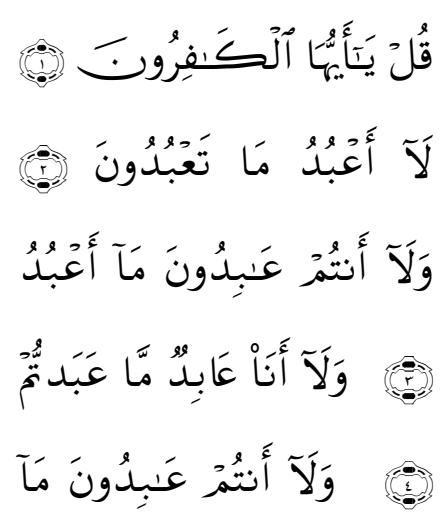




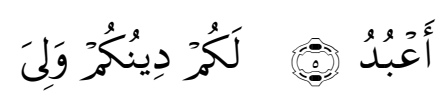

دين

"Katakanlah (Muhammad), "Wahai orang-orang kafir! Aku tidak akan menyembah apa yang kamu sembah, dan kamu bukan penyembah apa yang aku sembah, dan aku tidak pernah menjadi penyembah apa yang kamu sembah, dan kamu tidak pernah (pula) menjadi penyembah apa yang aku sembah. Untukmu agamamu dan untukku agamaku" (Q.S. Al Kafirun, 109: 1-6).

\section{3) Surat Yunus}

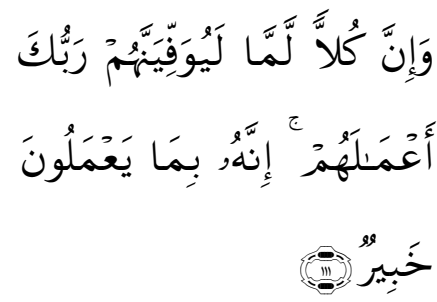

"Dan jika Tuhanmu menghendaki, tentulah beriman semua orang bumi seluruhnya. Tetapi apakah kamu (hendak) memaksa manusia agar mereka menjadi orang-orang yang beriman?" (Q.S. Yunus, 10: 220).

4) Surat al-Ghaasyiyah

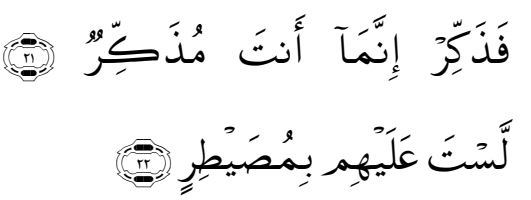

Maka berilah peringatan,
karena sesungguhnya engkau
(Muhammad) hanyalah pemberi
peringatan. Engkau bukanlah orang
yang berkuasa atas mereka (Q.S. Al-
Ghaasyiyah, 88: 21-22).

\section{b. Piagam Madinah}

Pasal 25 dalam Piagam Madinah merupakan perwujudan jaminan kebebasan beragama dan beribadah (freedom of religion) menurut ajaran agama masing-masing. Semua golongan yang mendukung konstitusi ini mendapatkan perlindungan dan jaminan kebebasan yang sama sebagaimana ditegaskan dalam pasal 26 sampai dengan pasal 35 , yang artinya:

“Kaum Yahudi Bani'Auf bersama dengan warga yang beriman adalah satu umah. Kedua belah pihak yakni kaum Yahudi dan kaum Muslimin bebas memeluk agama masing-masing. Demikian pula halnya dengan sekutu dan diri mereka sendiri. Bila di antara mereka ada yang melakukan aniaya dan dosa dalam hal ini, maka akibatnya akan ditanggung oleh diri dan warganya."

\section{c. Deklarasi Cairo}

Deklarasi Cairo dikeluarkan oleh Organisasi Konferensi Islam (OKI) pada tahun 1990. Pendahuluan dari deklarasi tersebut dapat ditarik menjadi beberapa poin, yaitu:

- Kebebasan manusia dalam masyarakat Islam konsisten dengan esensi kehidupannya, karena manusia dilahirkan dalam keadaan bebas dan bebas dari tekanan dan perbudakan.

- Persamaan adalah basis untuk memperoleh hak dan kewajiban asasi manusia.

- Islam mengakui persamaan antara penguasa dan rakyat yang harus tunduk kepada hukum Allah untuk menuntut 
siapapun yang menggangu ketentraman masyarakat.

- Islam mengakui persamaan semua manusia tanpa membedakan asal-usul, ras, jenis kelamin, warna kulit, dan bahasa.

Deklarasi Cairo terdiri dari 25 pasal yang mencakup masalah persamaan, kehormatan manusia, manusia sebagai keluarga, perlunya kerjasama antar sesama manusia tanpa memandang bangsa dan agamanya, keamanan rumah tangga, kebebasan beragama, perlunya solidaritas individu dalam masyarakat, pembebasan masyarakat dari kemiskinan dan kebodohan, perlindungan terhadap kesehatan masyarakat, pendidikan bukan hak melainkan kewajiban, dan sebagainya. Adapun poin dari keseluruhan pasal-pasal tersebut, yakni:

- HAM dalam Islam bersifat komprehensif (sosial, politik, budaya, dan ekonomi).

- HAM dalam Islam adalah karunia Allah (fitrah) dan bukan dari pemberian sesama manusia.

- HAM dalam Islam tidak terpisahkan dari syariah.

- HAM dalam Islam diderivasi dari ajaran Islam, yakni pernyataan dalam surat al-Israa ayat 70 yang menerangkan bahwa manusia merupakan makhluk yang mulia.

- HAM dalam Islam tidak absolute, karena dibatasi oleh obyek-obyek syariah dan bertujuan untuk menjaga hak serta kepentingan tiap individu yang ada dalam masyarakat (Hamid Fahmy Zarkasyi, 2011: 4-5).

\section{Batasan Beragama}

Kebebasan

Kebebasan beragama yang diberikan Islam mengandung sekurangnya tiga arti:

- Islam memberikan kebebasan kepada tiap individu untuk memeluk agama sesuai dengan kepercayaannya dan tidak ada paksaan bagi setiap individu untuk memeluk agama Islam.

- Setiap Muslim tidak diperkenankan mengganti agama dan keyakinannya tanpa ada alasan yang dapat diterima oleh Islam.

- Pemeluk agama Islam secara otomatis terikat oleh hukumhukum yang ada di dalamnya, sehingga tidak diperkenankan membuat ajaran maupun tafsiran-tafsiran baru yang bertentangan dengan dasardasar teologis (syariah dan aqidah).

Pembatasan hak-hak manusia dalam berfikir, berbicara, dan kebebasan beragama telah diterangkan dalam deklarasi London, yakni:

- Mencari ilmu dan mencari kebenaran merupakan kewajiban bagi Muslim.

- Setiap orang mempunyai hak untuk mengekspresikan pemikiran dan kepercayaannya sejauh dalam lingkup yang diatur dalam hukum, namun tidak seorang pun berhak menyebarkan kepalsuan atau menyebarkan berita yang 
mungkin mengganggu

ketentraman publik atau melecehkan harga diri orang lain.

- Merupakan hak dan kewajiban seorang Muslim untuk protes dan berjuang melawan penindasan, walaupun diharuskan melawan pemimpin.

- Tidak seorang pun berhak menghina, melecehkan kepercayaan agama lain, dan memprovokasi permusuhan publik.

Manusia bebas menyebarkan informasi selama tidak membahayakan keamanan masyarakat serta negara dan masih berada dalam koridor yang dibolehkan oleh hukum (Hamid Fahmy Zarkasyi, 2011: 55-56).

\section{Tujuan Kebebasan Beragama}

Implikasi langsung dari tercapainya hak kebebasan beragama tiap individu ialah terwujudkan kerukunan antar umat beragama. Perdamaian sekaligus kerukunan antar umat beragama hanya dapat dicapai, jika masing-masing golongan agama, di samping memelihara identitas masing-masing juga memelihara penghormatan kepada identitas golongan lain (menghormati kebebasan beragama). Hal ini berdasarkan atas perintah Allah dalam al-Qur'an, yakni:

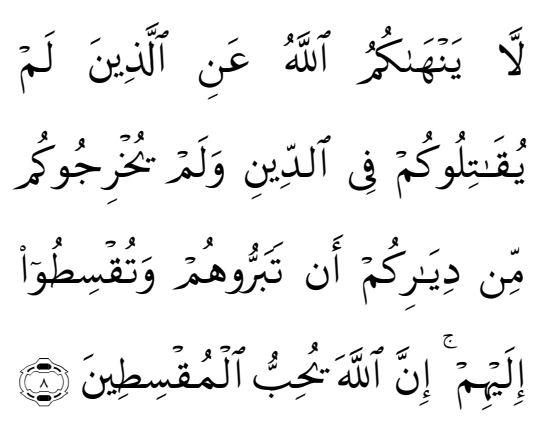

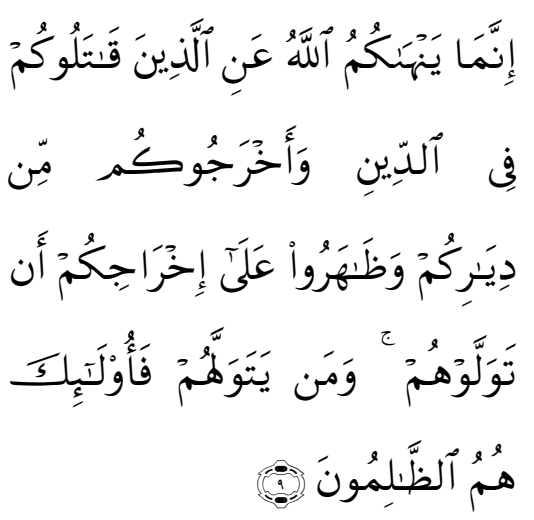

"Allah tidak melarang kamu berbuat baik dan berlaku adil terhadap orang-orang yang tidak memerangimu dalam urusan agama dan tidak mengusir kamu dari kampung halaman mu. Sesungguhnya Allah mencintai orang-orang yang berlaku adil. Sesungguhnya Allah hanya melarang kamu menjadikan mereka sebagai kawanmu orang-orang yang memerangi kamu dalam urusan agama dan mengusir kamu dari kampung halaman mu dan membantu (orang lain) untuk mengusirmu. Barangsiapa menjadikan mereka sebagai kawan, mereka itulah orang yang zalim" (Q.S, 60: 8-9).

Kerukunan umat beragama merupakan keadaan hubungan sesama umat beragama yang dilandasi toleransi, saling pengertian, saling menghormati, menghargai kesetaraan dalam pengamalan ajaran agamanya, serta kerjasama dalam kehidupan bermasyarakat berbangsa dan bernegara di dalam Negara Kesatuan Republik Indonesia berdasarkan Pancasila dan UUD 1945. Pemeliharaan kerukunan umat beragama merupakan upaya pelayanan, pengaturan, dan pemberdayaan umat beragama (Haidlor Ali Ahmad, 2010:14). 
Kerukunan hidup beragama merupakan proses yang dinamis yang berlangsung sejalan dengan pertumbuhan masyarakat itu sendiri. Pembinaan kerukunan hidup beragama adalah upaya yang dilaksanakan secara sadar, berencana, terarah, teratur, dan bertanggung jawab.

\section{KESIMPULAN DAN SARAN}

Kesimpulan yang dapat ditarik dalam pembahasan di atas adalah Kebebasan beragama dalam Islam dipahami sebagai prinsip bahwa setiap individu bebas memilih dan mengimani agamanya serta mengamalkan sepenuhnya ajaran-ajaran agama yang diyakininya. Islam memberi kebebasan kepada warganya untuk memeluk agama masing-masing dan tidak diperbolehkan memaksakan keyakinannya kepada orang lain.

Adapun saran yang perlu disampaikan, antara lain:

$>$ Forum Kerukunan Umat Beragama (FKUB), agar mengadakan konferensi atau pertemuan untuk mencegah dan menghadapi penyimpangan ataupun pelanggaran atas

\section{Daftar Kepustakaan}

Smith, Huston, Beyond The PostModern Mind, The Theosophical USA: Publishing House, 1989

Pengantar, Dalam Frithjof Schuon, "Mencari Titik Temu Agama-agama", Terj. Saafroedin Bahar, Jakarta: YOI, 1987 kebebasan beragama atas nama agama.

Majelis Ulama Indonesia (MUI) selaku perwakilan agama Islam di Indonesia diharapkan melakukan penyuluhan dan himbauan kepada umat Islam untuk melindungi hak setiap manusia dalam melaksanakan kehidupan agamanya secara sempurna. MUI juga diharapkan memberikan pemahaman kepada umat Islam, bahwa setiap individu berhak sepenuhnya memelihara integritas agamanya dalam kepatuhan dan ketakwaan atas prinsip agamanya dan kesetiaan terhadap integritas agamanya.

Kementerian Agama Republik Indonesia, hendaknya mengadakan konferensi atau suatu pertemuan yang mewakili perwakilan seluruh umat beragama untuk mempertimbangkan dan mencari suatu bentuk missi, zending dan dakwah agar dapat berjalan sesuai dengan batasan dan aturan agama masing-masing dan tidak mencederai hak individu atas kebebasan beragama dan perwujudan kerukunan umat beragama.
......................, The Common Vision of the World's Religions: Forgotten Truth, HarperSanFrancisco: New York, 1976
Nasr, Seyyed Hossein, Knowledge and the Secred, State University of New York Press: Albany. 1981


Sabri, Muhammad, Keberagaman Yang Saling Menyapa: Perspektif Filsafat Perennial, ITTIQA Press: Yogyakarta, 1999 Ahmad, Haidlor Ali (Ed.). 2010. Dinamika Kehidupan Keagamaan di Era Reformasi. Cet. 1. Jakarta: Kementerian Agama RI Badan Litbang dan Diklat Puslitbang Kehidupan Keagamaan.

Ali, Mukti. 1970. Dialoog Antar Agama. Jogjakarta: Yayasan Nida.

Alim, Muhammad. 2001. Demokrasi dan Hak Asasi Manusia Dalam Konstitusi Madinah dan UUD 1945. Cet.1. Yogyakarta: UII Press.

Asy'ari, Hasyim. 2011. Politik Hukum Kebebasan Beragama di Indonesia, dalam Jurnal Hukum Pandecta, Vol. 6, No. 1, Januari 2011. Semarang: Fakultas Hukum Universitas Diponegoro, hlm. 1-14.

Halim, Abdillah. 2010. Telaah Politik Hukum dan Kebebasan Beragama Terhadap UU No. 1/PNPS/1965 Tentang Pencegahan Penyalahgunaan Dan/Atau Penodaan Agama. Tesis tidak diterbitkan. Yogyakarta: Program Studi Hukum Islam Universitas Islam Negeri Sunan Kalijaga.

Kusdiyanto. 1997. Buku Pegangan Kuliah Metodologi Penelitian. Surakarta: Fakultas Ekonomi Universitas Muhammadiyah Surakarta.

Mantovani, Sarah Larasati. 2011. Tinjauan Yuridis UndangUndang No. 1 PNPS Tahun
1965 Tentang Pencegahan

Penyalahgunaan Penodaan

Agama Terhadap Kebebasan

Beragama di Indonesia

(Analisis Putusan Mahkamah

Konstitusi No. 140/PUU-

VII/2009). Skripsi tidak

diterbitkan. Tangerang Selatan:

Fakultas Hukum Universitas

Pamulang.

Mawdudi, Mawlana Abul A'la. 2000.

Cet. 2. Hak-Hak Asasi Manusia

Dalam Islam. Diterjemahkan

oleh Djajaatmadja, Bambang Iriana. Jakarta: Bumi Aksara.

Moleong, Lexy J. 1994. Metodologi Penelitian Kualitatif, Cet. 5. Bandung: Remaja Rosdakarya.

Nazir, Moh. 1988. Metode Penelitian. Jakarta: Ghalia Indonesia.

Sayogie, Frans. 2012. Hak Kebebasan Beragama Dalam Islam Ditinjau Dari Perspektif Perlindungan Negara Dan Hak Asasi Manusia Universal. Tesis tidak diterbitkan. Jakarta: Magister Hukum Kenegaraan Universitas Indonesia.

Sudjana, Nana. 1988. Tuntunan Penyusunan Karya Ilmiah (Makalah-Skripsi-Tesis-

Disertasi. Bandung: Sinar Baru.

Sumartana, Th; Agoeng, Noegroho; dan Qodir, Zuly. 2002. Pluralisme, Konflik, dan Perdamaian Studi Bersama Antar Iman. Yogyakarta: Pustaka Pelajar.

Tim. 1990. Ensiklopedi Nasional Indonesia Jilid 9. Jakarta: Cipta Adi Pustaka.

Zarkasyi, Hamid Fahmy. 2011. Islam HAM Dan Kebebasan Beragama. Jakarta: INSISTS. 